\title{
Organizations: Power/History/Imagination*
}

\author{
Stewart Clegg*
}

\begin{abstract}
The paper takes the assumptions of bounded rationality as the premise for organization theorizing. It draws a distinction between a science of objects and a science of subjects, arguing the latter as the more appropriate frame for organization analysis. Organization studies, it suggests, are an example of the type of knowledge that Flyvbjerg, following Aristotle, terms 'phronesis'. At the core of phronetic organization studies, the paper argues, there stands a concern with power, history and imagination. The core of the paper discusses power and the politics of organizing, to point up some central differences in approach to the key term in the trinity that the paper invokes. The paper concludes that organization theory and analysis is best cultivated not in an ideal world of paradigm consensus or domination but in a world of discursive plurality, where obstinate differences in domain assumptions are explicit and explicitly tolerated. A good conversation assumes engagement with alternate points of view, argued against vigorously, but ultimately, where these positions pass the criteria of reason rather than prejudice, tolerated as legitimate points of view. In so doing, it elaborates and defends criteria of reason.
\end{abstract}

Key-words : power, history, imagination, organization

\section{Resumo}

Este artigo parte do pressuposto do conceito de racionalidade limitada como premissa para a teoria das organizações. Faz-se uma distinção entre a ciência de objetos e a ciência de sujeitos, apontando a última como a mais apropriada para a análise da organização. Sugere-se que os estudos organizacionais são um exemplo do tipo de conhecimento que Flyvbjerg, seguindo Aristóteles, denomina phronesis. 0 artigo discute que no centro dos estudos organizacionais há uma preocupação com poder, história e imaginação. 0 artigo discute o poder e a política de organizar, para então apontar algumas diferenças na abordagem do termo- chave na tríade poder, história e imaginação. 0 artigo conclui que a teoria e análise organizacionais são mais bem cultivadas, não em um mundo ideal dos paradigmas do consenso ou da dominação, mas em um mundo de pluralidade discursiva, onde diferenças marcantes em pressupostos dominantes são explícitas, e toleradas explicitamente. Uma boa conversação deve estabelecer pontes entre pontos de vista alternados, contrapostos vigorosamente, onde essas posições utilizam o critério da razão ao invés do preconceito, toleradas como pontos de vista legitimados. Assim fazendo, a boa conversação elabora e defende critérios de razão.

Palavras-chave: poder, história, imaginação, organização

\section{Bounded rationalities and context dependence}

A central proposition of organization studies is that decision-making is always bounded in its rationality by the great depths and far reaches of uncertainty and ignorance within which it will always be constituted ${ }^{1}$. That is to say, because rationality is bounded it can never account for itself: hence reflexivity is inherent to its practice. Human rationality is always context dependent because, as Wittgenstein (1972) demonstrated unequivocally, no rule could ever account for its own interpretation - thus, context cannot be reduced to rules. All science

\footnotetext{
* This paper was initially presented to the 2002 APROS Conference in Hong Kong in December 2001. It draws on editorial material contained in the introductions to Stewart Clegg (ed.) Central Currents in Organization Studies: Contemporary Trends and Central Currents in Organization Studies: Frameworks and Application (both London: Sage, 2002), published as two boxed sets of four volumes each.

** Ph.D. - University of Bradford Management Centre. Profesor of Management - University of Technology, Sydney. PO Box 123 Broadway NSW 2007 - Australia. s.clegg@ uts.edu.au.

${ }^{1}$ There is some debate about the appropriate title for the endeavour represented here, as to whether it should be 'organization theory', 'organization analysis', organization science, 'organization studies', or just 'management' (see Clegg and Hardy, 1996). I have followed the convention established in the 'Handbook' of using the broader title.
} 
occurs in the context of what realist philosophers of science refer to as 'standing conditions'. These standing conditions provide for the prevalence of the sense that the science makes of the world of object-relations, against naturally occurring conditions. Standing conditions are definite sets of contextual experimental conditions, such as ensuring a sterile laboratory environment, maintaining a vacuum, or a stable temperature. Without these conditions, maintained by the experimentalist, the predicted relations that the research setting seeks to display would not occur. Thus, a context for stable object relations has to be artfully contrived so that the context has no effect other than that sought experimentally. A science of objects needs to appear to be context-free; otherwise, it cannot provide a general theory.

Put simply, iron filings should always display the same dispositional behaviour when introduced to the poles of a magnet, irrespective of whether the experiment occurs in Japan or the United States or who is the experimentalist. These variables simply are not important to the 'sense' that the filings make of their patterning around the magnetic poles. Which is to say, as phenomena from the object-realm, rather than the subject realm, they can make no sense whatsoever. Nor is it relevant to the sense that the experimentalist makes. They do not index the particulars of their own identity in making this sense.

Had we been thinking about how managers might respond to the twin poles of a strategic threat, rather than iron filings responding to a magnet, the situation would be very different. The patterns that emerge are not the result of laws that inexorably create a certain pattern. There is far more indeterminateness. Patterns are established by rules that are applied locally, in situ, by the actors themselves. These rules are not external - even though they may exist as such, as material traces, in manuals or procedures. They are, instead, the result of a complex mastery of skills that enable the actors to cope with new situations according to some categories for making sense that involves the application of member's implicit rules. That is what constitutes skill. But, once such skills are well learnt they become reflexively automatic. That is, they cannot be analyzed simply in terms of those rules that might be thought to constitute them. Such rules become themselves the unspoken and tacit ground of any action, action that is capable of improvising in unpredictable ways around and between any sense that the rules might make. Rules cannot account for their own interpretation in situ by actors. It is such interpretations that provide the social science sense of context. Studies that take these interpretations as their frame of reference are only ever as ontologically secure as these intersubjective interpretations are stable. If sensemaking changes, reality changes.

We should not be too voluntarist about sensemaking. One person's sense is rarely as binding as is any other's. All sense is made in a relational world and the relational space is three-dimensional. History, power and imagination constitute the three dimensions. History represents the dead weight of tradition, like a nightmare on the brain of the living, as Marx once had it. The rules for making this sense, and not some other, have an inertial, historical quality to them. They are such rules because they were established as such interpretive devices in the past. The second dimension concerns power. Without power being exercised in concrete episodic relations and thus disciplining, disposing and reproducing them, extant traditions could never be preserved (see Clegg [1989] from where this account is developed) or transformed, where an existing circuit of power is broken. Historical traditions change, not inexorably, but for reasons of power, imagination and context. The capacity to be able to conceive a difference - imagination - has to be allied to the capacity to make a difference - power. Subjects of rule can cut off their rulers' heads. Monarchies can tumble. What was sovereign becomes debased. What was rhetorically subject - the will of the people - can become rhetorically dominant. Imagination - the capacity to conceive a difference - is at the kernel of planned change.

Not all change is planned. And this is where context comes in. Context, the reader will recall, is a matter of stable sensemaking conditions. However, there are no guarantees of, or for, such conditions. They are ultimately subject to unpredictable, arbitrary and random variation. (My favourite example of such variation is the combined and interdependent impact of fleas, rats, viruses, technology, geography and climatic conditions in transforming the balance of power between lords and peasants in $14^{\text {th }}$ century Europe, ushering in the transformation of feudal relations of production - see the account in Clegg [1989]).

Natural science is full of cases of random variation: the impact of meteorites or of volcanic-induced climate changes (through the blanket effect of volcanic ash) on the eco-system would be cases in point. Random and 
arbitrary variation in the contextual standing conditions need not come just from some exogenous source of change, such as a meteorite or geological activity. While these are clearly important there are other, more mundane, sources of variation for social scientists to consider. For instance, in the sphere of organizations, all attempts at organized corporate sensemaking rely on the organization's power to secure this sense. Potentially, any organization's power to do this may be subject to erosion. Such erosion may be defined as a diminished capacity on the part of the actor (individual or corporate - in this case the latter, because organizational) to maintain the set of standing conditions that, contextually, enabled this power to structure particular episodes in terms of its preferences. Erosion may derive from the failure of existing imagination on the part of that power; success in implementing its imagination on the part of some other putative power, as well as random and arbitrary acts that serve to destabilize the existing context. At the margin, they can break existing circuits of power, refixing them on new passage points made obligatory.

Take a concrete organizational example. The historical constitution of bureaucratic rules may no longer make sense for some powerful actors who had traditionally framed them; for instance, their security might be undercut by the imagination of other possibilities by actors elsewhere - competitors or influential consultants. If actors choose to make organizational sense using some other rules, such as rules for 'new organizational forms', the new organizations will not necessarily be a variant on the same bureaucratic theme as before. As sense changes themes may change too because the ontological security of the putative phenomena under discussion is never given. It never can be because it can only ever rely on the intersubjective security of the sensemaking context as its guarantee. History, power and imagination all contrive to make such guarantees insecure.

\section{History/Power/Imagination}

History is the representation of what has elapsed, as a sense made from a momentary here-and-now that frames the retrospection that makes its sense possible. An element of contingency resides in those relevancies included and excluded by its retrospection. Imagination - by definition - cannot be controlled. And power is always potentially capable of being destabilized if it cannot secure the episodic conditions that contextually enable it to be powerful. History, power and imagination are both a mighty and unstable triangulation of forces. Working in harness, they can make particular intersubjective worlds of sensemaking seem stable, almost object-like, in their relations. When such conditions of and for sensemaking are achieved they become, simultaneously, both the object and subject of social science. That is to say they provide a context that can be assumed in both mundane and scientific sensemaking. A science of organizations thus seeks to objectivize those intersubjective capabilities that make its object - organizations - possible. (Some of this objectivization may well be accomplished by the use of power in the everyday world - creating organizations that appear to function according to rule. And organization theorists can assist in the creation of these if they choose. They have that right of choice. And negation.)

Intersubjective capabilities may work in ways that are, at any moment in their historical process, potentially ineffable because they are not produced according to rule. Ineffability may arise for many reasons. The imagination of actors may serve to innovate a rule not yet known. Consequently, any extant organizational order will always be rule-guided rather than rule-governed. There is no external experimentalist holding the conditions of history, power and imagination stable in order to maintain the existing benefits of doing so, although many of those who do benefit may be expected to try and act as if they were such experimentalists. However, there are no authoritative governors outside of everyday life. We know of neither divine rules for, nor secular scientific laws of, the social, outside of our construction of them. Only the existing winners and losers and the sense they make, and have made for them, of their human condition, can serve to secure the conditions of everyday life.

It is important to realize that these conditions are experienced, simultaneously, as both structure and agency. The rule guidedness that may be observed by social scientists is not the outcome of structures working on agents, as it is often represented as being. Rule guidedness is the outcome of actors and their practices situated in relation to structures which in turn are instantiated in practices: for example, the Highway Code produces 
rule-guided outcomes in terms of the semiotic significance of red and green traffic lights for motorists. It is not that red causes an absence of movement and green provokes a presence of movement. In certain contexts, there may be contradictory auditory sense datum to those that are visual. For instance, at the sound of an approaching ambulance, police or fire vehicle siren, the traffic at both the red and the green lights at an intersection may be stationary until the vehicle emitting the auditory sense datum has visibly passed the intersection. As practical experimentalists we understand the situational nature of both structures and actions and their mutual implication. Nonetheless, in organization theory we conventionally find research concentrating on one side or the other of the agency/structure divide (usually the structural side) rather than looking at questions about "what structural factors influence individual actions, how those actions are constructed, and their structural consequences" (FLYVBJERG, 2001: 138).

\section{Rationality}

Rationality is always situational. And because it is always contextually situational it is always implicated with power. No context stands outside power. If that were the case, then it would exists nowhere, outside of understanding, outside of possibility, outside of sense. As Foucault (1977: 27-28) says "power produces knowledge ... power and knowledge directly imply one another . . . there is no power relation without the creative constitution of a field of knowledge, nor any knowledge that does not presuppose and constitute at the same time power relations." In such a view rationalities and powers are fused. Different power actors will operate in and through different rationalities. The different rationalities will have their different rules for producing sense - at the more formal outer limits - for producing truth. In fact, sense and truth cannot be separated from the ensemble of rules that constitute them - and their obverse - as such.

To adopt a discursive analysis of rationality is to see what people say as the means whereby rationality and power become interwoven. People may be in a position to say anything, given the infinity of discourse, but they rarely surprise the well-grounded analyst with their discursive moves. Which is not to say that language games are predictable - although sometimes they are - but to suggest that they are explicable. We can understand and constitute the senses that are being made as well as the conditions of existence and underlying tacit assumptions that make such sense possible. And in this way we can begin to understand the different forms of agency that find expression in organizational contexts, where the players make sense of rules that they actively construct and deconstruct in the context of their action.

Rather than being law-like phenomena, rules are always constituted locally, in context, by the actors themselves, rather than being the objective instantiation of a general principle or law. Contextualism implies that whatever regularities occur empirically will always be situational. Researchers need to understand that these are not likely to be the result of either remote laws operating behind the backs of the actors concerned nor are they likely to be the result of an idiosyncratic researchers interpretation of the scene in question. To the extent that the researcher has researched the situational ethics of the context at hand then they will have a sound grasp of the socially and historically conditioned context within which sense is made. With these understandings researchers can avoid the relativism that they are sometimes charged with: their understandings will be framed within deeply embedded foundations that the actors find normal and acceptable to use. In matters of interpretation there is always room for disagreement and it is no different for the organization researcher. One interpretation is rarely as good as another. Some will always be more plausible in terms of the contexts within which they are produced and received.

Unlike phenomena in an object realm, where the matter at hand has no understanding of itself, actors who possess understanding always populate organizations. Their understanding extends both to an appreciation of each other as well as those artefacts that they constitute (and which sometimes constitute them - for instance, a machine operator) and with which they interact. Thus, organizations are always more subject-realms than merely object realms, albeit that as objects of reflection, they can be subjected to object-like treatment and routines. But this does not inescapably secure their nature as something ontologically just so. Of course, there is no shortage of theories in organization studies that presume to offer abstract context independent concepts but on close examination these theories always betray the origins of their context dependent assumptions. It could 
not be otherwise. These assumptions may be more or less tacit or more or less reflexive but their context cannot be excluded because such context always defines the relevancy of the phenomena that any theory addresses. Like its precepts for practice, organization theorists always study what is bounded rationality. And they do so using bounded rationality.

\section{Marx, Nietzsche and Theorizing Power}

The broad social theory agenda within which power has been constituted in the wider social sciences was shaped in its outer coordinates by a continuing debate with Marx and Nietzsche. The debate with Marx was conducted most notably by Steven Lukes (1974), the English political philosopher, especially in his use of the concept of 'hegemony', a concept that had become inexorably associated with the work of the Italian Marxist and theorist of civil society, Antonio Gramsci (1971).

Nietszche's influence could be seen most clearly in the work of the French historian, Michel Foucault (1977) and, of course, the German sociologist Max Weber (1978). . Each of these theorists had a significant impact on scholarship on power in general, and on scholarship in organization theory in particular. Foucault introduced a new mode of analysis of power. Foucault was opposed to any such opposition as 'science' and 'ideology' or 'true' and 'false' consciousness. He opposed the assumptions of imperial and imperious correctness contained in either side of the oppositions: the security of the ground from which ex cathedra judgements about the 'truth' could be dispensed could invariably, he would argue, be shown to be historically changeable rather than constant. For Foucault, one should not think of power without also thinking of knowledge. Power operated not only in a prohibitive way, telling one what one could not so but it also operated through knowledge, through everyday ways of sensemaking that were more or less institutionalised in disciplinary knowledge, in a permissive, positive manner - constructing the normalcy of the normal.

Foucault opened up a front that has been principally influential in non-US analysis. Indeed, there are few North American theorists who seem to find Foucault of interest. For instance, when Behlül Üsdiken and Yorgo Pasadeos (1995) made a comparison of co-citation networks in European and US organization studies, they identified Foucault as the seventh most cited researcher in the European journals, just behind Weber. Neither Weber nor Foucault, nor many others influential in the European list, made it into the comparable US-based lists. One may take this as a particular example of the general point concerning the relations of power, imagination and history.

In the context of discussions of power, the European-influenced imagination has veered far from that predominant in the US, where, with some rare exceptions, empirically specifiable proceduralism, if not empiricism, has tended to be dominant. Quite different histories have emerged in consequence. Indeed, there is a sense in which, in the ways that the central issue of power has been addressed, fundamental questions about the nature of inquiry have been handled in quite distinct ways. In the European context, for those scholars for whom Weber and Foucault, for instance, are not just dead white male European social theorists but a source of vital questions about the nature of research, foundational assumptions, methodologies, evidence and ethics, a quite different pragmatics of research flourishes (TEN BOSS, 2000). The dominant model in the US has clearly been one of 'positivism'. At issue have been the unequivocal establishment of a casual relation and the direction of that causality in determining matters of power between phenomena treated as if they were a part of the object world. Hence, major organization writers on power, such as Pfeffer (1993), have never engaged in any serious way with the debates in social theory around Lukes' (1974), Foucault's (1977) or Clegg's (1989) conceptions of power. The silence is extraordinary - it as if these works and those debates do not exist. Never having been addressed we have no way of knowing how they are regarded.

What can explain this absence, this silence? Pfeffer (1993) has highlighted the value of normal science and paradigm consensus, suggesting that it will produce greater scholarly reputations and better resource allocations. Thus, positivism is doubly functional for Pfeffer: it enables one to create an illusion of consensus in both theory and reality. So, those voices that might disturb the consensus by raising issues that cannot be answered within the causal, objectivist apparatus must be ignored. Instead, research should search for the nature of reality as that which is open to inspection rather than that which is beneath the surface, beyond the gaze, of 
an objective observer recording what is. In Wicks and Freeman's (1998: 125) terms, positivists seek to be finders not makers of reality (even as they artfully construct their domain assumptions and standing conditions to do so). Essentially, they are naive descriptivists: neutral observers of what just happens to be. They take no stance towards the nature of being: in other words, they simply register that which is without reflection - which could only be speculative and prescriptive - or why it might be that way. Their ethic of value freedom places them beyond ethics - it is a kind of ethics that you have when you don't presume any other ethics. Of course, these articles of faith are designed to protect science from contamination by other, lesser forms of knowledge.

One may argue that while the nature of reality is unequivocally real - it is 'out there' - our ways of knowing it as such are somewhat more contestable. While we have highly elaborated codes for making sense of phenomena - such as the methods of empirical science - we should recognise these for the codes they are. They are sophisticated ways of narrating the stories that matter to us as scientists and people, of giving them credence, of passing them on in the world. Reality cannot be represented in some propositionally pure form that is untouched by the context of meaning in which it is embedded. That Hobbes saw and described the phenomena of power in causal terms, using metaphors of springs, flywheels, and force, was not surprising in a world in which scholars sought signs that would enable them to unravel the mechanical nature of the universe and of being in it. In speaking in the scholarly language of his day Hobbes bequeathed a view of power that could not encapsulate action at a distance, that could not conceptualize how the standing conditions for any action might constitute the mechanics of its outcome, and could not cope with the power of abstracted representations - its own included.

\section{Narratives and the Meaninglessness of Science}

One conclusion that we can draw from the above is that all inquiry is fundamentally narrative - it tells a story about states of affairs that is more or less plausible within the conventions of particular narrative communities. Or as Wittgenstein (1972) puts it, science is a language game - like any other. Or in Rorty's (1991) similar terms, experience ordered though our sense data may cause us to hold certain views of the matter in question but it cannot tell us which views we should be considering in the first place. The insight is old, however. Weber (1948: 143) quoted Tolstoy in a speech to students at Munich University in 1918 to this effect:

Science is meaningless because it gives no answer to our question, the only question important for us: "What shall we do and how shall we live? That science does not give an answer to this is indisputable. The only question that remains is the sense in which science gives 'no' answer, and whether or not science might yet be of some use to the one who puts the question correctly.

One consequence of positivism in organization studies has been to obscure this most basic question. It has created an epistemic context in which such a question cannot even be considered. (As an aside, if all those who accuse Weber of being a positivist, hung up on the fact/value distinction, were to take more cognisance of this remarkable essay, they would be hard put to maintain that belief.) Instead, ethics are something else outside the questions one asks of reality as a scholar: that certain causal regularities may be empirically observed of a phenomena does not enable one to ask why these regularities and not some others? How, for instance, is authority achieved as a set of patterned preferences whose prevalence demonstrates its facticity? At the outset, organization studies never asked such questions concerning power in organizations - it simply took it for granted. Hence, having no conception of power other than as A getting B to do something that B would not otherwise do, it was able to ignore all the important ethical questions. Such as, why should ownership and control of a phenomenon such as capital have dominance over other things? How does such domination become authority ${ }^{2}$ ?

\footnotetext{
${ }^{2}$ There are not only ethical considerations to these questions: there are also descriptive implications as well. For instance, the assumption that relations of capital ownership, and the relations of employment that they entailed, were dominant, has meant that a major focus of organization studies has been on the organization as an envelope of activity. Thus, it was sensible for the Aston School to use the number of employment contracts that an organization has as an operational proxy of the size of the organization, and then to hypothesise that as this number goes up, then other attributes of the objective organization structure, such as the degree of formalization, will increase inexorably. But, of course, there are many kinds of relation and many kinds of contract. Employment contracts are not the totality. For instance, many organizations have many sub-contracts with many other organizations, in supply chains or networks, which extend their resources and capabilities enormously without increasing their size.
} 
Pfeffer (1993) calls for moral rearmament around functionalism, because to do so will suppress internal conflict concerning methods and epistemologies. Such conflicts he regards as dangerous, corrosive of moral authority, and destructive of professional reputation and discipline. Order is what is required. On the contrary: intellectual communities - just as political communities - that suppress conflict do so at considerable risk to their vitality. As Flyvbjerg (2001: 108) suggests "suppressing conflict is suppressing freedom, because the privilege to engage in conflict and power struggle is part of freedom. He goes on to suggest that "perhaps social and political theories that ignore or marginalize conflicts are potentially oppressive, too." I think he is right.

Organization theory, in as much as it would only allow for debate on its own terms - the Pfeffer option - would be repressive, oppressive and antithetical to the spirit of an intellectually open society. It is conflict that sustains openness: without such conflict the genuine democracy that is essential to the articulation of reason is lacking. Reason resides not so much in what is said, as Habermas (1971) argues, as in the formal conditions that constitute the conditions within which what is said can be expressed. The more democratic a discourse the more legitimate will be the inevitable conflicts of interest that arise and the less there will be barriers to their expression. And there is every reason for democratic discourse as the basis of science: if there are barriers to expression, if certain styles of work are demonised or disdained, then there is no open society. Sterility, banality, orthodoxy - this is what ensues when debate is stifled in the name of order. In political science it is called totalitarianism. It is what happens when power overwhelms imagination - especially the imagination of those out with of power, whose imagination could rewrite history.

\section{Implications}

One of the advantages of Foucault's approach to power is that it "integrates rationality and power, knowledge and power, reason and power, truth and power" (FLYVBJERG, 2001: 124). Power is the axis. Power frees imagination and power writes history. Without power poverty, disease, and despair is what faces the human condition. Only power - the capacity to make a difference to existing conditions of existence in ways that are significant for the actors concerned - can free imagination. Otherwise it rots in the gutters of history. Power writes history. That the histories we inherit have overwhelmingly been those of the dominant actors strutting their stuff in the various stages of the human comedy - the men, the whites, the colonialists, the rich, the powerful, the educated - is hardly surprising. Life on the margins, in service, bondage or slavery of one kind or another, rarely affords room, time or tools for intense reflection. As Foucault (1977: 27) suggests, "we should abandon a whole tradition that allows us to imagine that knowledge can exist only where the power relations are suspended and that knowledge can develop only outside its injunctions, its demands and its interests." On the contrary, as he goes on to suggest, power produces knowledge, they are directly implicated in each other. Reflexivity is essential to understanding this relation, suggests Foucault. We need to be able to see how power actually functions in context.

Conventionally, it is proposed that organization studies should "model reality and search for essentialist underlying structures via scientific study" (Wicks and Freeman, 1998: 130). Essentially, in philosophical terms, this is the propositional strategy that was outlined by Wittgenstein (1922) in the Tracatus LogicoPhilosophicus. And in the Philosophical Investigations (1972) the same author decisively repudiated such a position. The earlier philosophy suggests that one should seek to make ideal representations, in an eternal, unchanging way, through absolutely lucid and unequivocal propositional statements, concerning the essential qualities of the social world of organizations - as if they were as simple to read as iron filings around magnetic poles. The later Wittgenstein (1972) suggested that one should explore a phenomena first hand instead: he used a very clear representational, cartographic metaphor to make his point.

Imagine this case: I tell someone that I walked a certain route, going by a map which I had prepared beforehand. Thereupon I shew him the map, and it consist of lines on a piece of paper; but I cannot explain how these lines are the map of my movements, I cannot tell him anything rule for interpreting the map. Yet I did follow the drawing with all the characteristic tokens of reading a map (Wittgenstein, 1972: 653).

Wittgenstein wrote about maps on several occasions (GASKING AND JACKSON, 1967). His use of maps, rather than establishing the unequivocal mapping of a reality in a precise representation, were more a means of 
knowing a phenomenon, such as the City of London, to be used to enable one to walk highways and byways, side streets and main streets. In parlance more contemporary than that which Wittgenstein had available to him, one who aspires to explore the underbelly and side streets of a city would probably be considered a 'rough guide'. Rather than construct some Whiggish history of the discourse that peaks in the latest paper in the most prestigious journal I have sought to show you some of the byways and side streets, not just the main highways through which traffic passes today (see Chan's [2001] discussion of 'Whiggish history'.).

Wittgenstein's metaphor of the city can be extended further. Organizations are somewhat like the city: organic, constantly recreating themselves, tearing out the present heart and soul, routing new freeways through the existing geography, creating new aesthetics that overwhelm but never entirely eradicate the old, leaving traces of lost realities, past triumphs, and buried beliefs. Having no static essence the city can never truly be represented cartographically any more than organizations can ever be truly represented propositionally. The city is its conflicts, its power struggles over real estate, its aesthetic imagining of its possibilities, as well as its history. It is alive, organic, contested, peopled, a space for human possibilities, impossible dramas, overweening ambitions, and great tragedy. Just like organizations.

Science is not the voice of an omniscient narrator, cudgelling all those whom are not true believers or defenders of the faith, into abandoning their heresies and joining the one true church. As my metaphors are meant to suggest, I would think religion a better way of describing such 'defences' (DONALDSON, 1985). Lacking faith in the existence of an underlying, all-knowing but ultimately unknowable order, one should instead gradually allow narratives "to unfold from the diverse, complex and sometimes conflicting stories that people, documents and other evidence tell them. This approach leaves ample scope for readers to make different interpretations and to draw diverse conclusions" (FLYVBJERG, 2001: 86).

Hence, the possibility of multiple interpretations is admitted and structured into the accounting that one does. "There are multiple interpretations of events and different concepts and classificatory schemes could be used to describe phenomena" (WICKS AND FREEMAN, 1998: 134). However, this is not an embrace of nihilism, an abrogation of perspective to the relativism that all views are equal. One does not simply celebrate difference for the sake of difference. Not all accounts are as good as others. Some are more useful for the purpose at hand than are others. Which of various accounts will be most useful will depend, precisely, on the purpose at hand. The criteria of reasonableness must include some notion of fitness for purpose: some accounts will better serve the task at hand and thus better enable people to accomplish relevant goals than will others. And that is a compelling reason why organization studies should not be rigidly scientistic in its forms of method and writing: these may not be the most appropriate forms of communication for the particular audience one is seeking to address. And as Stablein (1996) has taught us, in writing organization studies, (as anything else), the intended audience should not be ignored.

Not being positivistic is not the same as an abandonment of scientific rigour. A persuasive narrative must provide reasons - it must be reasonable - and recognise that reasons, reason and positivistic science are not the same thing. A compelling narrative will be one that persuades rigorously, aesthetically, and through the conventions of its chosen mode of discourse. It can never be paradigm-independent, in the jargon. Hence, it does not mean "social scientists should stop using control groups, double-blind studies, regression analyses, and other techniques that are associated with social scientific research" (WICKS AND FREEMAN, 1998: 137). However, it is how and for what purposes one uses these which matters. As Flyvbjerg (2001: 166) stresses, "we must drop the fruitless efforts to emulate natural science's success in producing cumulative and predictive theory; this approach simply does not work in social science." The use of such methods should be oriented towards understanding and explaining contextual particulars rather than be seen as elements for a law-like grand theory of predictive power. Such a colossal immodesty in the face of the many standing conditions that cannot be controlled is, at worst, sheer stupidity or at best, the worst kind of cultural cringe. Case studies, documentary analysis or other forms of narrative are not, a priori, second-rate science, just because the methodology of physics places great store on the experimental method.

Methodologically, the experimental method creates a set of standing conditions in the laboratory such that one may create the effects that one is theoretically interested in investigating. One proceeds through what, early in 
the methodology of modern science, the philosopher John Stuart Mill referred to as the method of systematic co-variation. Using this method one manipulates the parameters of the experiment in such a way that one systematically varies theoretical controls in the experiment until causal efficacy is established. Different parameters are held constant - such as temperature or length of time that there is exposure to some variable while others are systematically varied. Once the desired causality is achieved one seeks to replicate that experiment systematically, in order to ensure the constancy of results, given the standing conditions. It is this strategy of systematic co-variation that is the fundamental axiom of laboratory-based sciences, such as physics, chemistry and molecular biology.

There are no laboratories in nature. By definition, the laboratory is an artfully contrived environment. When we look at naturalistic phenomena that varies in nature through time and space the research questions that we seek to address are such that one cannot control their parameters. For instance, with the global warming hypothesis, one cannot isolate a low-lying Pacific atoll, such as Kiribati, and systematically increase the ecological heat surrounding it, perhaps by systematically thinning its immediate ozone layer. And, even if one could, there is the not so small ethical question of what happens to the nature so fried - including the Kirribatians and other organisms that inhabit the atoll. The ecology, like the subject of other historical sciences such as evolution of species, linguistics, or the galaxy, is not something that can be artfully constructed into a temporally and spatially bounded sphere of co-variation.

In any historical science - and it should be clear that organization theory is such a science in the conception being advanced here - there are an enormous number of variables, great complexity, unique actors, and no possibility of artful laboratory closure. One response to this is to restrict explanation to probabilistic statements that prevail at the level of ontological adequacy (MCKELVEY, 2002). We can compare the behaviour of a statistical model, based on trend data, as an idealized pattern against which parallel properties of real-world phenomena that are defined as falling within the scope of a theory may be contrasted in a model-phenomena link. So, for instance, Diamond $(1998,423)$ can predict the model parameters of statistical probability for an event occurrence, such as the number of births of boys and girls in any population, without being able to predict the outcome for any specific case before its conception. There are other approaches available in the historical sciences as well, such as the use of naturally occurring experiments (GARFINKEL, 1967), an approach used not only by ethnomethodological investigators but also cultural anthropologists and evolutionary biologists.

There is one great advantage when researching socially constructed phenomena: provided we are able to translate the language in use we are able to interpret the understandings that its subjects have of themselves and the phenomena that they found salient. Ultimately, we can seek to understand interpretively the stories that people construct to explain reality for them. (While this is easier if we are able to be co-present and ask directly historical traces can also yield great returns.) Essentially, the human condition is a narrative condition - it is a story of unfolding origins, sometimes charted, but more often, unknown destinations, and ways of telling the stories that matter. These ways of telling are what we can refer to as narrative techniques.

Narrative techniques are innumerable. In Australia today, where I live, I know various people who steer their lives through various stories. Some people interpret their lives through Christian gospel, others Aboriginal Dreamtime, and, in one case, I know someone who believes mostly in positivism. But positivism, the Dreamtime, and the gospels attributed to Christ, are all stories. There are different techniques for producing such stories that each speaker/hearer/writer/audience will translate appropriately, by refining their technique in terms of the craft parameters that forms of narrative life makes plausible.

While all narratives that establish prime movers display a degree of fetishism - sometimes extreme - whether it be a fetish of the Rainbow Serpent, God, or the Law of Science - what characterises more ontologically adequate accounts of phenomena is the relation of these narrative prime movers and proximate causes. In natural history evolution is one such metaphysic; in organization studies it can also serve that function for some cases of large-scale populations over relatively long periods of time, such as Diamond (1998) studies, in the cases of the social organization of peoples, their foodstuffs, ecologies, crafts and germs. Narratives make sense not simply by fetishizing certain techniques but because they also address existential dilemmas in meaningful ways. That is how Rainbow Serpents, Sons of God and Laws of Science are named into Being. They speak to 
our human and organizational conditions of existence in ways that we find useful and desirable. They may propose ways of extending our powers and freeing our imagination while sometimes they represent ways of enslaving the imagination of others or limiting their powers.

There is an ethical dimension to the contextual, pragmatic conception of organization studies as a human science with a natural history. Being a part of the social scenes that $\mathrm{s} / \mathrm{he}$ investigates, the organization analyst has a responsibility towards the subjects of that science. When we investigate organizations we are messing with people. We are not just observing rats in a laboratory or iron filings round a magnet. We address the impact of major structures of society on the lives of ordinary people. We have a responsibility to these people as human communities - just as much as to the professional communities of methods and theories that sustain us. Indeed, if we cannot effect a conversation, a dialogue, between the two, then it is not clear what we are doing that is useful - although it may be very clear what privileges we are abusing by doing so. Hence, it matters not only how we study what we study but also how we choose to study such phenomena in the first place. We can address ourselves to issues that are arcane and inconsequential for all but an elite community of scholars - perhaps no more than two or three people. Or we can engage in the human comedy and address things that matter to people in their everyday lives.

\section{Conclusion}

Signs of past traces of power, imagination, and history prefigure present organization studies. Such pasts are not privileged as something already elapsed and fixed but remain relevant to contemporary understanding only in as much as that understanding makes its sense of them (BURRELL, 1997: 5). Such past practices, sedimented structures and materialised meanings, in the memorable rallying cry, 'weigh like a nightmare on the brain of the living' (MARX, 1969, p. 30). Yet, the living cannot easily shrug them off for they frame our condition even as we cease to believe in the ways in which they have been represented in the past.

The past of organization studies is not so much another continent but a landscape that can be constantly redrawn in terms of contemporary aesthetics, techniques, and concerns. It is the landscape on which we project our dreams and our nightmares, our imagined futures and our fabled pasts; it is the context that frames our powers as it defines our limits.

Today, no one can pretend to understand the human condition that does not understand the organizations in which it is constituted, constrained and transformed. Organization studies should be at the core of the study of the human condition, because without such subject matter - how, why, and in what ways, we collectively organize, dispute, do and change the things we do - we would have nothing of any consequence to discuss. Organizations frame the outer limits of our humanity and how we choose to express it - whether through the systems of slavery that extracted gold from the black bodies in the green cane plantations of the America's or the learning bureaucracies that first propelled white men into Space.

In conclusion, organization analysis implies a substantial moral responsibility, if only because the history of human achievement is a history of organization. The responsibility should not be shrugged off lightly or reduced to a mere technical discourse, to a physics of necessity made out of social contingency. It should be acknowledged for what it is: a conversation with the living and the dead about those conditions of social existence that we imagine for the future, as well as a struggle to establish powers that can transcend those histories we inherit, in the service of those futures we can imagine. 


\section{Bibliography}

Burrel, G. (1997) Pandemonium, London: Sage.

Chan, A (2001) Critically Constituting Organization, Amsterdam: Benjamins.

Clegg, S. R. (1989) Frameworks of Power, London: Sage.

Clegg, S. R. (1990) Modern Organizations: Organization Studies in the Postmodern World, London: Sage.

Diamond, J. (1998) Guns, Germs and Steel: A Short History of Everybody for the Last 13,000 Years, New York: Vintage.

Donaldson, L. (1985) In Defence of Organization Theory: A Response to the Critics, Cambridge: Cambridge University Press.

Flyvbjerg, B. (2001) Making Social Sciences Matter: Why social inquiry fails and how it can succeed again, Cambridge: Cambridge University Press.

Foucault, M. (1977) Discipline and Punish, Harmondsworth: Penguin.

Garfinkel, H. (1967) Studies in Ethnomethodology, Englewood Cliffs, NJ: Prentice Hall.

Gasking, D. A. T. and Jackson, A. C. (1967) "Wittgenstein as a Teacher", in L. Fann (ed.) Ludwig Wittgenstein: the Man and His Philosophy, Sussex: Harvester.

Gramsci, A. (1971) Selections from the Prison Notebooks, London: Lawrence and Wishart.

Habermas, J. (1971) Knowledge and Human Interests, London: Heinemann.

Lukes, S. (1974) Power: A Radical View, London: Blackwell.

Marx, K. (1976) Capital, Harmondsworth: Penguin.

McKelvey, B. (2002) "From Fields to Science", forthcoming in Robert Westwood and Stewart Clegg, (eds) Point/Counterpoint: Central Debates in Organization Theory, London: Blackwell.

Pfeffer, J. (1995) "Barriers to the advancement of organizacion science: paradigm development as dependent variable", Academy of Management Review, 18, 599-620.

Rorty, R. (1991) Objectivity, relativism, and truth, Cambridge: Cambridge University Press,

Stablein, R. (1996) "Data in Organization Studies", pp. 509-525 in Clegg, S. R., Hardy, C., and Nord, W. (eds) Handbook of Organization Studies, London: Sage.

ten Boss, R. (2000) Fashion and Utopia in Management Thinking, Amsterdam: Benjamins.

Üsdiken B. and Pasadeos Y. (1995) "Organizational Analysis in North America and Europe: A Comparison of Co-citation Networks" Organization Studies, 16, 3, 503-526.

Weber, M. (1948) "Science as a Vocation", pp. 129-158 in H. H. Gerth and C. W. Mills (eds) From Max Weber: Essays in Sociology, London: Routledge and kegan Paul.

Weber, M. (1976) The Protestant Ethic and the Spirit of Capitalism, London: Allen and Unwin.

Weber, M. (1978) Economy and Society, Berkeley: University of California Press.

Wicks, A. C. and Freeman R. E. (1998) "Organization Studies and the New Pragmatism: Positivism, Anti-positivism, and the Search for Ethics", Organization Science, 9, 2, 123-140.

Wittgenstein, L. (1922) Tractatus Logico- Philosophicus, London: Routledge and Kegan Paul, 1922.

Wittgenstein, I. (1972) Philosophical Investigations, Oxford: Blackwells. 